\title{
Genetic associations of lactose and its ratios to other milk solids with health traits in Austrian Fleckvieh cows
}

\author{
A. Costa, ${ }^{1 *}$ C. Egger-Danner, ${ }^{2}$ G. Mészáros,${ }^{3}$ C. Fuerst, ${ }^{2}$ M. Penasa, ${ }^{1}$ J. Sölkner, ${ }^{3}$ and B. Fuerst-Waltt ${ }^{3}$ \\ ${ }^{1}$ Department of Agronomy, Food, Natural Resources, Animals and Environment, University of Padova, Viale dell'Università 16, \\ 35020 Legnaro (PD), Italy \\ ${ }^{2}$ ZuchtData EDV-Dienstleistungen GmbH, Dresdner Str. 89/19, A-1200 Vienna, Austria \\ ${ }^{3}$ Department of Sustainable Agricultural Systems, Division of Livestock Sciences, University of Natural Resources \\ and Life Sciences Vienna (BOKU), Gregor Mendel-Str. 33, A-1180 Vienna, Austria
}

\section{ABSTRACT}

The genetic correlations $\left(\mathrm{r}_{\mathrm{a}}\right)$ of milk lactose percentage (LP), lactose yield (LY), and ratios of LP to other milk solids with udder, metabolic, and fertility disorders have not been assessed in dairy cattle so far. To evaluate the potential role of milk lactose as indicator of cow health, 142,285 lactation records of 84,289 Austrian Fleckvieh cows were analyzed with univariate and bivariate animal models. Milk traits were on a $150-\mathrm{d}$ basis and health traits were coded as binary (0/1). Other than LP and LY, 3 new phenotypes were defined and included in the present study, namely the lactose-to-fat, lactose-to-protein, and lactose-tosolids ratios. The most heritable trait was LP (0.566 $\pm 0.008)$ and heritability of LY was much lower $(0.145$ $\pm 0.005)$. Heritability estimates close to 0.50 were assessed for the ratios. The frequency of health disorders was higher in multiparous cows yielding milk with low LP $(\leq 4.553 \%)$ compared with cows yielding milk with high LP $(\geq 5.045 \%)$. Heritabilities of health traits were in the expected ranges, with the highest estimate for ovarian cysts (CYS; $0.037 \pm 0.004)$ and the lowest for retained placenta $(0.005 \pm 0.001)$. Mastitis (MAS) genetically correlated with LY $(0.518 \pm 0.057)$; considering that the amount of synthesized lactose is the key regulator of milk volume, this result confirmed that high-producing cows are more genetically susceptible to MAS than low-producing animals. Similar to MAS, ketosis (KET) was also positively genetically associated with LY $(0.420 \pm 0.077)$ and a weak and unfavorable $\mathrm{r}_{\mathrm{a}}$ between KET and lactose-to-protein ratio was estimated $(0.159 \pm 0.077)$. The $\mathrm{r}_{\mathrm{a}}$ of LY with milk fever (MFV) and CYS were approximately 0.20 . The $\mathrm{r}_{\mathrm{a}}$ of LP with MAS, KET, and MFV were negative $(-0.142$ on average), supporting the idea that LP is a potential

Received October 19, 2018.

Accepted January 4, 2019.

*Corresponding author: angela.costa.1@phd.unipd.it health indicator. Genetic correlations between health traits ranged from zero (retained placenta with MAS and CYS) to $0.463 \pm 0.090$ (MAS and MFV). Results of the present study suggest that LP has potentiality to be used as indicator trait to improve udder health in Austrian Fleckvieh population.

Key words: cattle, lactose, mastitis, fertility, genetic correlation

\section{INTRODUCTION}

Dairy cow health has become a target of several breeding programs worldwide, with increased weight in selection indexes (Pfeiffer et al., 2015; Fuerst-Waltl et al., 2016; Pryce et al., 2016). Apart from consumer sensitivity to animal welfare, concerns of farmers and the scientific community about impaired cows' productivity and performance are reasons for this increased interest (Egger-Danner et al., 2010; Oltenacu and Broom, 2010). In fact, health and metabolic status of cows affect milk yield (MY), composition, and technological properties (Leitner et al., 2011; Cinar et al., 2015; Fox et al., 2015). Economic losses associated with major diseases affecting dairy cows are usually indirect and differ among countries (Gonçalves et al., 2018; Hadrich et al., 2018; Mostert et al., 2018). A case of mastitis (MAS) costs around $€ 300$ in Europe, with substantial differences according to the severity (ICAR, 2018). In Austria, the cost of a MAS case is slightly higher (€341), and it includes milk embargo due to medical treatments (Fuerst-Waltl et al., 2016); however, considering all outflows, peaks of $€ 600$ per single MAS case have been reported in Austrian dairy farms (Braunvieh Austria, 2018). Rollin et al. (2015) estimated a cost of $\$ 444$ per case of MAS occurring in the first 30 DIM in US dairy cattle. Moreover, Gohary et al. (2016) estimated an economic loss of US\$203 per case of subclinical ketosis in Canada, and Mostert et al. (2018) reported that health costs generally increase with parity order. 
Considering that the genetic variance and heritability of most common diseases are low, the use of correlated indicator traits in milk could be beneficial to speed up genetic responses by increasing the accuracy of breeding values (Koeck et al., 2012; Egger-Danner et al., 2015; Pryce et al., 2016). Lactose, the main solid in bovine milk, has been recently proposed as a potential indicator trait of both udder health and metabolic status of the cow (Haile-Mariam and Pryce, 2017; Løvendahl and Riis Weisbjerg, 2017; Ebrahimie et al., 2018). Lactose derives from blood sugars, and it has been estimated that the udder uses 60 to $85 \%$ of circulating glucose in ruminants for lactose synthesis (Zhao, 2014). In high-producing dairy cattle, the amount of synthesized lactose can exceed $4.4 \mathrm{~kg} / \mathrm{d}$ (Aschenbach et al., 2010). The lactation curve of lactose yield (LY) resembles that of MY and, thus, blood glucose uptake by udder is maximum at the peak of lactation. The LY produced by the mammary gland is in charge of determining water uptake from the cytosol and thus of milk volume.

Negative energy balance, and consequently ketosis (KET), arises when cows are not able to cope with the high demands of milk production, mainly because the absorption of glucose from the intestine by sodiumdependent glucose transporters is often not enough to cover the metabolic demand of dairy cows, especially at the beginning of lactation (Aschenbach et al., 2010). Several authors reported that KET decreases both LY and lactose percentage (LP; Cant et al., 2002; Reist et al., 2002; Fox et al., 2015; Larsen and Moyes, 2015); however, in high-producing cows, MY is the main anabolic scope, and the udder demand for glucose is a priority (Aschenbach et al., 2010), as the deficit of blood glucose may be counterbalanced by other sources; namely, greater conversion of AA into glucose in liver and reduced delivery of glucose in nonmammary tissues. Therefore, glucose availability at the udder level is maintained and LY and MY are not strongly impaired even in the presence of negative energy balance (Aschenbach et al., 2010). Although genetic and phenotypic mechanisms relating to blood sugar and milk sugar are not fully known, high availability of blood glucose, positive metabolic energy status of cow, and good expression of glucose transporters are always translated into high LY and LP (Ouweltjes et al., 2007). Indeed, LP was found to be $15 \%$ lower in cows fed a low-energy diet (Beerda et al., 2007) and negatively related to milk BHB (Larsen and Moyes, 2015), a ketone body derived from liver gluconeogenesis from fatty acids and used as indicator of KET (Larsen and Moyes, 2015). Lactose percentage is the physiological point at which the osmotic equilibrium between milk and blood is reached and, therefore, the call of water by udder from circula- tory system stops. Nevertheless, to our knowledge only Belay et al. (2017) investigated the relationships of KET with milk LP and LY in Norwegian Red cows. In their study, phenotypic and genetic correlations with LP and phenotypic correlation with LY were close to zero, whereas the genetic correlation with LY was 0.16. This finding supported the idea that udder LY should not be impaired by low blood glucose and negative energy balance in specialized dairy cows, as mechanisms related to homeorhesis exist in specialized breeds and, thus, body reserves are used to maintain MY (Bauman and Currie, 1980; Zhao, 2014). Nevertheless, even if a low availability of blood glucose in high-yielding cows may not impair LY and MY, it could affect other physiological processes related to fertility, such as ovulation. Francisco et al. (2003) estimated a positive association between milk LP and number of days from first to second postpartum ovulation. Moreover, Buckley et al. (2003) reported favorable correlations between LP and fertility traits in Holstein cows, thus suggesting that LP could be used as indicator of reproductive performances in cattle. Miglior et al. (2006) reported a favorable correlation between LP and cows' longevity, with higher and lower risk of being culled for cows yielding milk with low and high LP, respectively. In addition, some studies proposed fat-to-lactose ratio as an indicator of metabolic status of cows (Reist et al., 2002; Ederer et al., 2014; Haile-Mariam and Pryce, 2017), as the estimated correlation with cow energy balance in the first $10 \mathrm{~d}$ after calving was -0.589 (Reist et al., 2002).

With respect to udder health, LP has been reported to be negatively associated with SCC (Gillon et al., 2010), the most widely used milk indicator of IMI and MAS. Moreover, LP has been recently considered a useful and reliable indicator of MAS (Ebrahimie et al., 2018; Marchitelli et al., 2018) due to its relation with MAS-related changes in milk minerals, electrical conductivity, and osmotic equilibrium. When MAS occurs, the SCC increases and the permeability of the cell membranes changes. These mechanisms lead to a drop of LP in milk and to an increase in both MAS-related minerals from blood ( $\mathrm{Na}$ and $\mathrm{Cl}$ ) and milk electrical conductivity (Fox et al., 2015). Nevertheless, almost all genetic and phenotypic studies that have investigated IMI and included LP and LY have dealt with SCC rather than with real diagnoses of MAS recorded by veterinarians or farmers. From a genetic point of view, because MAS is positively related to MY, genetic selection to increase the productivity in the last half century has resulted in dairy cows being more susceptible to udder inflammation (Oltenacu and Broom, 2010). Moreover, concerns exist regarding the use of SCC as a phenotype to improve MAS resistance. In fact, as SCC are mostly composed of white blood cells, one may wonder if the 
selection for depressing this trait would impair immune system of the cows and thus weaken their ability to face inflammations and infections (Heringstad et al., 2000; Rainard et al., 2018). Despite these evident biological aspects relating LP and LY with cow metabolism and udder health, a proper investigation on lactose and its ratios with other milk solids have not been performed so far. The associations of LP and LY with KET, MAS, and other common metabolic and reproductive diseases of dairy cows, such as milk fever (MFV), retained placenta (RET), and ovarian cysts (CYS), have also not been investigated. Finally, it is worth pointing out that LP is routinely recorded in several countries in the framework of official milk recording schemes, which means that wide phenotypic information is available at the population level. Therefore, the aims of our study were to (1) estimate genetic variation and heritability of LP, its ratios with other milk solids, and LY, and (2) assess their genetic associations with major disorders in a large data set of Austrian Fleckvieh (FV) cows.

\section{MATERIALS AND METHODS}

\section{Milk Data}

For the observation period between January 2010 and March 2018, more than 4 million test-day records from $175,154 \mathrm{FV}$ cows in 10,530 herds were retrieved from the official database of the Austrian milk recording system. The FV is the dominant cattle breed in Austria (75.3\% of total registered cows) and lactation MY, fat percentage $(\mathbf{F P})$, and protein percentage (PP) average $7,345 \mathrm{~kg}, 4.16 \%$, and $3.42 \%$, respectively (ZAR, 2018). Milk of FV cows is characterized by lower SCC (mean of 175,484 cells $/ \mathrm{mL}$, median of 61,000 cells $/ \mathrm{mL}$ ) than milk of other cattle breeds, such as Brown Swiss and Holstein (ZuchtData, 2017). Milk yield (kg/d) was available for each test-day record, as well as LP, FP, and $\mathrm{PP}$, which were predicted through mid-infrared spectroscopy using a MilkoScan FT6000 (Foss Electric A/S, Hillerød, Denmark). The SCC (cells/mL) was determined through Fossomatic FC (Foss Electric $\mathrm{A} / \mathrm{S}$ ) and values were retained if between 1,000 and 10,000,000 cells/mL. Test-day MY, LP, FP, or PP outside mean \pm 3 standard deviations and those outside the range 5 to 400 DIM were discarded from the data set, resulting in 2,489,996 records. Finally, test-day LY $(\mathrm{kg} / \mathrm{d})$, fat yield $(\mathbf{F Y} ; \mathrm{kg} / \mathrm{d})$, protein yield $(\mathbf{P Y} ; \mathrm{kg} / \mathrm{d})$, and daily SCC (cells/d) were calculated by multiplying MY by LP, FP, PP, and SCC, respectively.

Considering the standard average productive life of FV in Austria (ZuchtData, 2017), observations of cows until fifth parity were kept in the data set. Parity- specific age at calving was restricted to 20 to $40 \mathrm{mo}$ for first-, 32 to 58 mo for second-, 44 to 72 mo for third-, 54 to 86 mo for fourth-, and 66 to 100 mo for fifth-parity cows. This resulted in 2,471,422 test-day records.

To move from test days to lactation data, the test interval method proposed by the International Committee for Animal Recording (ICAR, 2017) was used. As most common disorders in lactating cows usually show higher incidence, additive genetic variance, and heritability in early and midlactation, the focus in the present study was on the first 150 DIM. Therefore, 150d MY, LY, FY, PY, and SCC were calculated as

$$
\begin{aligned}
\mathrm{C}_{150} & =\mathrm{I}_{0} \mathrm{~T}_{1}+\mathrm{I}_{1} \times\left[\left(\mathrm{T}_{1}+\mathrm{T}_{2}\right) / 2\right]+\mathrm{I}_{2} \times\left[\left(\mathrm{T}_{2}+\mathrm{T}_{3}\right) / 2\right] \\
& +\ldots+\mathrm{I}_{\mathrm{n}-1} \times\left[\left(\mathrm{T}_{\mathrm{n}-1}+\mathrm{T}_{\mathrm{n}}\right) / 2\right]+\mathrm{I}_{\mathrm{n}} \times \mathrm{T}_{\mathrm{n}},
\end{aligned}
$$

where $\mathrm{C}_{150}$ is the cumulative MY, LY, FY, PY, or SCC between 5 and 150 DIM; $\mathrm{I}_{0}$ is the interval between 5 DIM and the first available test day; $I_{1}, I_{2}$, and $I_{n-1}$ are the intervals (d) between 2 consecutive test days; $I_{n}$ is the interval between the last test day and 150 DIM; and $\mathrm{T}_{1}, \mathrm{~T}_{2}, \mathrm{~T}_{\mathrm{n}-1}$, and $\mathrm{T}_{\mathrm{n}}$ are test-day MY, LY, FY, PY, or daily SCC. The 150-d average LP, FP, and PP were computed using the following formula (ICAR, 2017):

$$
\mathrm{AP}=\left(\mathrm{C}_{150} / \mathrm{MY}_{150}\right) \times 100,
$$

where AP is the 150-d average LP, FP, or PP; $\mathrm{C}_{150}$ is the 150-d LY, FY, or PY; and $\mathrm{MY}_{150}$ is the 150-d MY. The 150-d average SCC was calculated by dividing 150d SCC by $\mathrm{MY}_{150}$, and values were then log-transformed to $\mathrm{SCS}$ as $\mathrm{SCS}=3+\log _{2}(\mathrm{SCC} / 100,000)$, to reach a Gaussian-like frequency distribution. Moreover, lactose-to-fat ( $\mathbf{L}: \mathbf{F})$, lactose-to-protein $(\mathbf{L}: \mathbf{P})$, and lactoseto-solids (L:S) ratios were calculated using the 150-d average LP, FP, and PP. The final data set consisted of 284,193 lactation records of 113,722 cows from 24,326 contemporary groups, which were defined as herd-year of calving of the cow $(\mathbf{H Y})$. All cows calved between January 2010 and October 2017 and were offspring of 4,293 sires and 83,131 dams.

\section{Health Data}

Details of the monitoring of cow health in Austria can be retrieved from Fuerst et al. (2011) and EggerDanner et al. (2012). To keep the most reliable information, diagnoses of MAS, KET, MFV, CYS, and RET were retained in the data set if collected in farms with more than $75 \%$ of diagnostic data submitted electronically by veterinarians. According to diagnoses, the observation period was between -10 and 150 DIM, except 
for RET, which was diagnosed from calving to 7 DIM. Similarly to the approach of Koeck et al. (2010a,b), each disorder was treated as a binary trait $(0=a b-$ sence, $1=$ presence) based on whether or not the disorder was diagnosed within the time interval considered. To check the frequency of MAS, KET, MFV, CYS, and RET at different levels of milk LP, lactation data were grouped into 3 classes of LP, according to mean LP \pm 2 standard deviations. The classes were created within primiparous and multiparous cows.

\section{Genetic Parameters Estimation}

A subset of $50 \%$ of the contemporary groups were randomly selected from the full data set, resulting in 142,285 lactation records from 84,289 cows, of which 14,340 had more than 2 calvings. The subset was representative of the variability of the entire data and, thus, variance and covariance components of MAS, KET, MFV, CYS, and RET, as well as of 150-d MY, LY, LP, ratios, and SCS, were estimated on the subset through univariate and bivariate analyses, respectively; this allowed to limit computational memory and time. A linear model was chosen to estimate genetic parameters of the studied traits, including health traits, which is the same approach used for routine Austrian-German genetic evaluation (Fuerst et al., 2011). In a comparative study, Koeck et al. (2010a,b) reported that linear models were reliable tools for genetic analysis of health traits. The general form of the mixed linear animal model was

$$
\mathbf{y}=\mathbf{X b}+\mathbf{Z a}+\mathbf{W} \mathbf{p}+\mathbf{V q}+\mathbf{e},
$$

where $\mathbf{y}$ is the vector of phenotypic records of the trait; $\mathbf{b}$ is the vector of fixed effects of parity (from first to fifth), age at calving within parity (3 classes for firstparity cows: $<28,28-30$, and $>30 \mathrm{mo} ; 3$ classes for second-parity cows: $<41,41-44$, and $>44$ mo; 3 classes for third-parity cows: $<53,53-57$, and $>57 \mathrm{mo}$; and 1 class for fourth- and fifth-parity cows), and month-year of calving (94 levels); a is the vector of random animal additive genetic effects; $\mathbf{p}$ is the vector of random permanent environmental effects; $\mathbf{q}$ is the vector of random HY effects; $\mathbf{e}$ is the vector of random residuals; and $\mathbf{X}, \mathbf{Z}, \mathbf{W}$, and $\mathbf{V}$ are incidence matrices relating the corresponding effects to the dependent variable. All the analyses were performed using ASReml 4.1 (Gilmour et al., 2015).

Heritability was calculated as ratio of additive genetic to phenotypic variance (i.e., sum of additive genetic, permanent environmental, HY, and residual variances) and repeatability was the ratio between sum of addi- tive genetic and permanent environmental variances to phenotypic variance. Genetic $\left(\mathbf{r}_{\mathbf{a}}\right)$ and phenotypic $\left(\mathbf{r}_{\mathbf{p}}\right)$ correlations were computed as

$$
\mathrm{r}=\frac{\operatorname{cov}_{1,2}}{\sqrt{\sigma_{1}^{2} \times \sigma_{2}^{2}}},
$$

where $\operatorname{cov}_{1,2}$ is the additive genetic or phenotypic covariance between trait 1 and trait $2 ; \sigma_{1}^{2}$ is the additive genetic or phenotypic variance of trait 1 ; and $\sigma_{2}^{2}$ is the additive genetic or phenotypic variance of trait 2 .

The reliability of the pedigree provided by ZuchtData (Vienna, Austria) was checked with the software CFC 1.0 (Sargolzaei et al., 2006), and more than half of the individuals had coefficients of inbreeding between 0 and $5 \%$. Ancestors of target cows were traced back 4 generations, which resulted in 195,356 individuals for the subset.

\section{RESULTS AND DISCUSSION}

\section{Descriptive Statistics and Pearson's Correlations}

Descriptive statistics calculated on the full data set $(\mathrm{n}=284,193)$ showed that $150-\mathrm{d}$ MY averaged $4,157 \mathrm{~kg}$ (Table 1), which corresponds to an average daily MY of $27.7 \mathrm{~kg}$. Averages of FP and PP were 4.03 and $3.28 \%$, respectively. Means of FP and PP were expected to be lower than those of the whole lactation because the present study focused on the first 150 DIM. Indeed, ZAR (2018) reported average FP and PP of 4.16 and $3.42 \%$, respectively, and Fuerst-Waltl et al. (2016) reported $\mathrm{FP}$ of $4.12 \%$ and $\mathrm{PP}$ of $3.45 \%$ for first-lactation FV cows. For the same breed, Ederer et al. (2014) reported a milk composition in early lactation similar to that of the present study. The average LP (4.83\%) was close to the value (4.84\%) assessed by Ederer et al. (2014); however, comparisons with the literature are difficult due to paucity of studies on FV focusing on early and midlactation and including LP in the list of investigated milk traits. Some authors evaluated the effect of breed on milk composition and also estimated least squares means of LP for FV or Simmental cows. Overall, in those studies, milk LP of Simmental was $4.75 \%$ (Kedzierska-Matysek et al., 2011) and $4.71 \%$ (Gottardo et al., 2017), and it was also significantly lower than milk LP of Holstein-Friesian $(P<0.01$; Kedzierska-Matysek et al., 2011). The L:F, L:P, and L:S averaged 1.21, 1.48, and 0.40, respectively, and their coefficients of variation ranged from 5.25 (L:S) to $12.19 \%$ (L:F). Somatic cell score was low (1.77 units) if compared with findings obtained for the whole lactation 


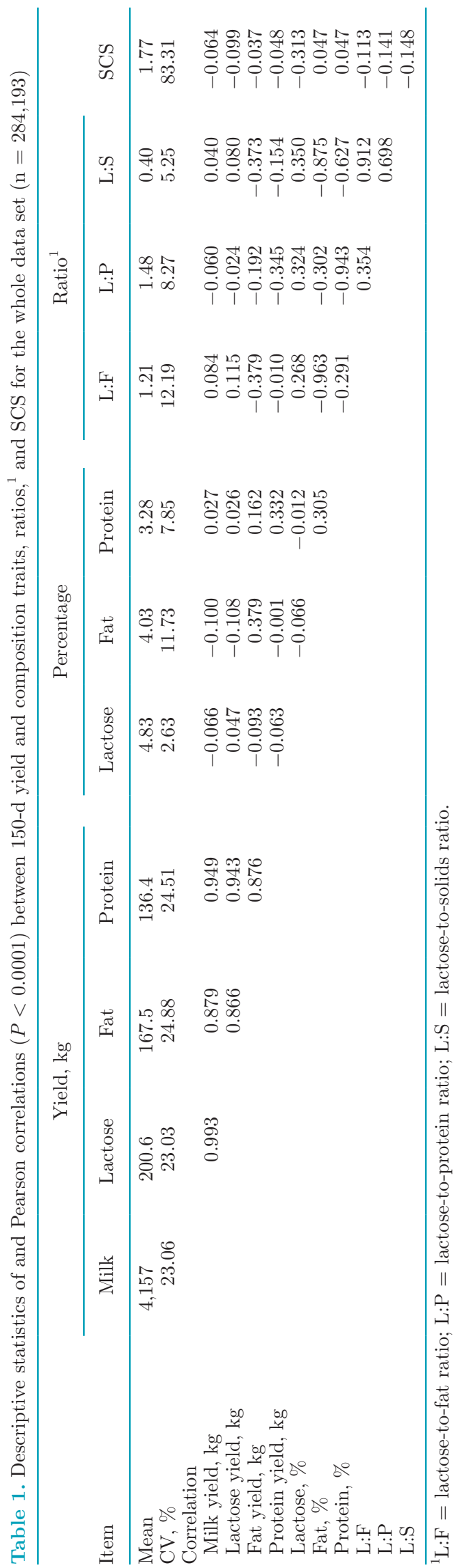

of FV and other breeds, but similar to the value (1.90) reported by Koeck et al. (2010b) for the same breed in a similar observation period (8-100 DIM). Indeed, milk SCC is lower in early than late lactation both for physiological reasons and because of the dilution effect.

Overall, the strongest Pearson correlation (0.993) was assessed between MY and LY (Table 1). This estimate was similar to the value (0.99) reported by Sneddon et al. (2015) in a New Zealand multibreed study and confirmed the strong physiological relationship between the 2 traits. Lactose yield weakly correlated with all traits, and LP was moderately associated with ratios (from 0.268 with L:F to 0.350 with L:S). Lactose-tofat ratio and L:P were moderately associated (0.354), and correlations of L:S with L:F and L:P were strong (0.912 and 0.698, respectively). Moreover, ratios were negatively weakly associated with SCS.

\section{Frequency of Health Disorders}

Contrary to the trend of LP, the incidence of diagnosed cows for health disorders increased with parity order (Table 2); this suggests that older cows yielded milk with lower LP and were more prone to get sick than younger animals. In particular, for MFV, the frequency increased considerably from 0.20 (first-parity cows) to $6.00 \%$ (fifth-parity cows); these distributions were similar to those reported by Egger-Danner et al. (2012) in Austria. Moreover, Ederer et al. (2014) assessed frequencies of KET and MFV across parities that were 0.60 and $2.80 \%$, respectively. In studies including other popular dairy breeds, such as Holstein, the incidence of KET was usually higher $(4.10 \%$; Koeck et al., 2013). The incidence of CYS was slightly lower than that (7.70\%) reported by Hooijer et al. (2001) in Dutch Black and White cows.

As expected, moving from the low-LP to the high-LP class, SCS decreased in both primiparous and multiparous cows. In particular, SCS was highest $(3.538 \pm$ 1.764 ) in the low-LP class in multiparous cows (Table $3)$, whereas the lowest SCS $(1.014 \pm 1.130)$ was assessed in the high-LP class of primiparous cows. Overall, the incidence of CYS slightly decreased from high to low LP. With regard to MFV, primiparous were less susceptible than multiparous animals; in fact, the greatest incidence $(3.76 \%)$ was found in the low-LP class of multiparous cows. The incidence of RET was slightly higher in the low-LP class compared with medium- and high-LP classes. In all other cases, the frequencies increased from high to low LP. In fact, the frequencies of MAS, KET, and RET of the low-LP class were 1.33 , 1.41 , and 1.02 times those of the high-LP class in primiparous animals, respectively. Considering multiparous cows, the frequencies of MAS, KET, MFV, and 


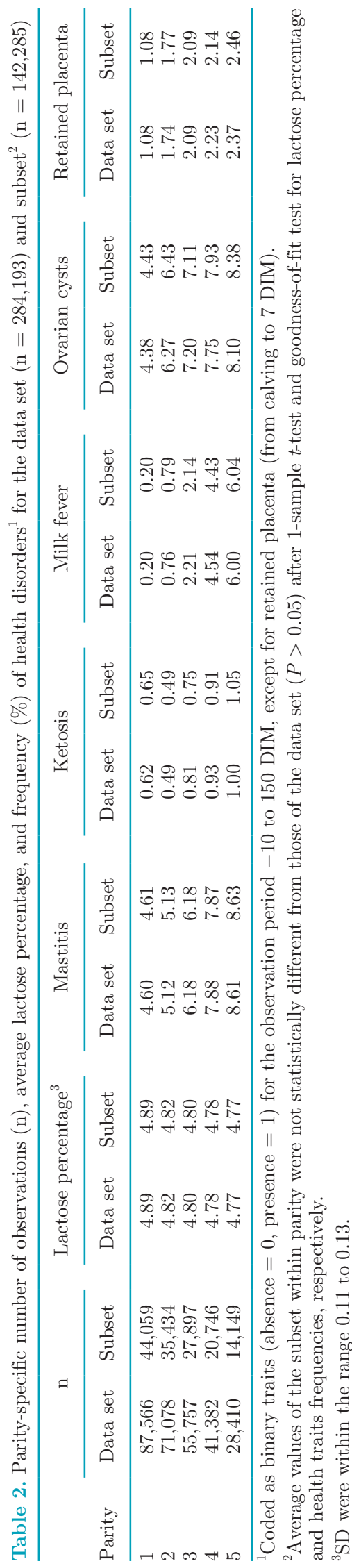

RET of the low-LP class were 2.33, 1.27, 1.83, and 1.17 times those of the high-LP class, respectively. Regarding CYS, its incidence somehow decreased moving from high to low LP in both primiparous and multiparous cows, suggesting that, for some reasons, cows with high LP were more susceptible to CYS. Overall, frequencies of diagnosed disorders in first-lactation cows were lower than those detected in cows in subsequent lactations. In particular, first-parity cows were at much lower risk of developing MFV at calving, likely because they did not suffer from metabolic stress caused by both previous lactation and dry period. Comparing the incidence of health disorders within classes of LP, fewer differences for first-lactation cows compared with other lactations were generally detected (Table 3 ).

\section{Variance Components and Heritability}

Heritabilities of the investigated traits ranged from $0.005 \pm 0.001$ (RET) to $0.566 \pm 0.008$ (LP; Table 4). Similar estimates for LP were reported by Miglior et al. (2007) for Canadian Holsteins and by Stoop et al. (2007) for first-calving Holstein cows in the Netherlands using test-day data. Lactose yield was the least heritable $(0.145 \pm 0.005)$ among milk-related traits, but this estimate was comparable with heritabilities of 0.125 and 0.180 reported by Tiezzi et al. (2013) in Italy and Sneddon et al. (2015) in New Zealand, respectively. Moreover, this value was similar to that $(0.140)$ reported by Costa et al. (2018) in Italian Holstein. Ratios were moderately heritable, with estimates from 0.445 \pm 0.008 (L:F) to $0.538 \pm 0.008$ (L:S), but it was not possible to compare our estimates with the literature due to absence of studies including the same traits. Mastitis, KET, MFV, CYS, and RET were lowly heritable and estimates were similar to those reported by Pryce et al. (2016) and Egger-Danner et al. (2015), who reviewed genetic parameters of most common disorders of dairy cows. In particular, heritability of MAS in the literature ranges from 0.02 to 0.08 , with differences due to breed or statistical approach (Egger-Danner et al., 2015). Focusing on the period from 51 to 150 DIM, Koeck et al. (2010b) estimated heritability of 0.02 for MAS in FV cows. Heritability of KET in the present study was lower than estimates (0.01 to 0.08) retrieved from the literature and assessed using linear models (Pryce et al., 2016). Regarding MFV, studies dealing with linear models reported an average heritability of 0.03 (Pryce et al., 2016), which is higher than the value computed in the present study. Ederer et al. (2014) reported heritability of 0.034 for MFV in a data set of FV cows. Fertility disorders were lowly heritable as well (Table 4). Development of CYS $(0.037 \pm 0.004)$ was the most heritable health trait, and the estimate was 
Table 3. Mean (SD) of SCS and frequency (\%) of health disorders ${ }^{1}$ across classes of lactose percentage ${ }^{2}$ in primiparous and multiparous cows

\begin{tabular}{|c|c|c|c|c|c|c|c|c|}
\hline Class & $\begin{array}{c}\text { Lactose } \\
\text { percentage range }\end{array}$ & $\mathrm{N}$ & SCS & Mastitis & Ketosis & $\begin{array}{l}\text { Milk } \\
\text { fever }\end{array}$ & $\begin{array}{l}\text { Ovarian } \\
\text { cysts }\end{array}$ & $\begin{array}{l}\text { Retained } \\
\text { placenta }\end{array}$ \\
\hline \multicolumn{9}{|c|}{ Primiparous } \\
\hline Low & $4.200-4.664$ & 2,402 & $2.454^{\mathrm{a}}(1.564)$ & $6.70^{\mathrm{a}}$ & $0.83^{\mathrm{a}}$ & $0.25^{\mathrm{b}}$ & $3.46^{\mathrm{b}}$ & $1.25^{\mathrm{a}}$ \\
\hline High & $5.117-5.300$ & 1,705 & $1.014^{\mathrm{c}}(1.130)$ & $5.04^{\mathrm{b}}$ & $0.59^{\mathrm{a}}$ & $0.29^{\mathrm{a}}$ & $4.69^{\mathrm{a}}$ & $1.23^{\mathrm{a}}$ \\
\hline \multicolumn{9}{|c|}{ Multiparous } \\
\hline Low & $4.180-4.553$ & 5,400 & $3.538^{\mathrm{a}}(1.764)$ & $11.52^{\mathrm{a}}$ & $0.93^{\mathrm{a}}$ & $3.76^{\mathrm{a}}$ & $5.78^{\mathrm{c}}$ & $2.56^{\mathrm{a}}$ \\
\hline
\end{tabular}

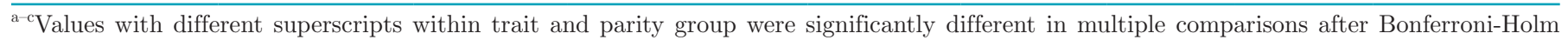
step-down adjustment $(P<0.05)$.

${ }^{1}$ Coded as binary traits (absence $=0$, presence $=1$ ) for the observation period -10 to 150 DIM, except for retained placenta (from calving to DIM 7).

${ }^{2}$ Classes of lactose percentage were defined according to mean $\pm 2 \mathrm{SD}$.

almost equal to the value (0.039) estimated by Koeck et al. (2010c) in the same breed using a linear model, but lower than the heritability (0.102) assessed by Hooijer et al. (2001) in a smaller data set of 15,562 Dutch Black and White cows. Heritability of RET $(0.005 \pm 0.001)$ was also similar to the estimate $(0.007)$ reported by Koeck et al. (2010c) for Austrian FV.

Differences with other studies could be due to (1) breed, (2) effects considered in the model, and (3) criteria adopted for recording health data. In addition, nonlinear models generally tend to slightly overestimate additive genetic variance (Heringstad et al., 2000); in fact, Heringstad et al. (2005) estimated higher heritabilities for KET (0.14 to 0.16) and MFV (0.09 to 0.13) in Norwegian Red cows using a threshold model. Moreover, with the same model, Neuenschwander et al.
(2012) estimated greater heritability for KET (0.09) in Holsteins. Similarly, the adoption of probit and logit models resulted in higher heritabilities of MAS (0.06 to 0.08 ) in FV cows (Koeck et al., 2010a). Overall, heritabilities of fertility disorders were in agreement with the literature; in particular, Koeck et al. (2010c) reported heritabilities of $0.060,0.006$, and 0.007 for RET using logit threshold sire, linear sire, and linear animal models, respectively, in FV cows. Comparably, CYS was found more heritable with threshold model, with estimates ranging from 0.050 (Zwald et al., 2004) to 0.077 (Koeck et al., 2010c), if compared with the present and other studies that adopted linear models to analyze data (0.040; Koeck et al., 2010c).

Because we considered 150-d traits in the present study, the repeatability of milk-related traits is the sim-

Table 4. Phenotypic variance ${ }^{1}\left(\sigma_{p}^{2}\right)$, heritability (SE), repeatability (SE), and proportion (\%) of variance explained by herd-year of calving effect $\left(\mathrm{c}^{2}\right)$ for 150-d production, SCS, and health traits for the subset $(\mathrm{n}=$ $142,285)$

\begin{tabular}{|c|c|c|c|c|}
\hline Trait & $\sigma_{p}^{2}$ & Heritability & Repeatability & $c^{2}$ \\
\hline \multicolumn{5}{|l|}{ Production traits $^{2}$} \\
\hline Milk yield, kg & $705,970.2$ & $0.151(0.005)$ & $0.213(0.003)$ & 50.37 \\
\hline Lactose yield, kg & $1,678.98$ & $0.145(0.005)$ & $0.204(0.003)$ & 50.73 \\
\hline Lactose, $\%$ & 13.97 & $0.566(0.008)$ & $0.624(0.003)$ & 6.16 \\
\hline $\mathrm{L}: \mathrm{F}$ & 21.82 & $0.445(0.008)$ & $0.497(0.003)$ & 9.22 \\
\hline $\mathrm{L}: \mathrm{P}$ & 13.14 & $0.474(0.008)$ & $0.507(0.003)$ & 12.52 \\
\hline $\mathrm{L}: \mathrm{S}$ & 0.42 & $0.538(0.008)$ & $0.574(0.003)$ & 7.26 \\
\hline $\mathrm{SCS}$ & 2.12 & $0.183(0.007)$ & $0.308(0.004)$ & 10.02 \\
\hline \multicolumn{5}{|l|}{ Health traits ${ }^{3}$} \\
\hline Mastitis & 55.61 & $0.017(0.003)$ & $0.050(0.004)$ & 6.11 \\
\hline Ketosis & 7.00 & $0.006(0.002)$ & $0.033(0.004)$ & 3.56 \\
\hline Milk fever & 18.45 & $0.015(0.002)$ & $0.042(0.004)$ & 2.63 \\
\hline Ovarian cysts & 58.75 & $0.037(0.004)$ & $0.071(0.004)$ & 10.55 \\
\hline Retained placenta & 17.07 & $0.005(0.001)$ & $0.027(0.004)$ & 2.74 \\
\hline
\end{tabular}

${ }^{1}$ Values in italics have to be multiplied by $10^{-3}$.

${ }^{2} \mathrm{~L}: \mathrm{F}=$ lactose-to-fat ratio; $\mathrm{L}: \mathrm{P}=$ lactose-to-protein ratio; $\mathrm{L}: \mathrm{S}$ = lactose-to-solids ratio.

${ }^{3}$ Coded as binary traits $($ absence $=0$, presence $=1$ ) for the observation period -10 to 150 DIM, except for retained placenta (from calving to 7 DIM). 
ilarity of values of the trait on the same cow in different lactations. Therefore, comparisons of repeatabilities of MY, LY, LP, and ratios with those estimated with testday repeatability models are not fully correct. Both LP and ratios had moderate to high repeatabilities (from $0.497 \pm 0.003$ of L:F to $0.624 \pm 0.003$ of LP). Even with different statistical approaches and designs, similar findings for LP were reported by Stoop et al. (2007), Sneddon et al. (2015), and Visentin et al. (2017). The low repeatability for LY suggested that the synthesis of this component in the udder differed across lactations of the same cow in the first 150 DIM. Somatic cell score exhibited a moderate repeatability $(0.308 \pm 0.004)$, slightly lower than that reported by Tiezzi et al. (2013) and Visentin et al. (2017). Health traits, on the other hand, were scarcely repeatable, with values that ranged from $0.027 \pm 0.004$ (RET) to $0.071 \pm 0.004$ (CYS); the low repeatability of health traits was expected, as they are supposed to be occasional events and their frequency across lactations are usually close to zero, due to culling, therapy, and other management strategies.

The greatest contribution of the HY effect to the phenotypic variance was found for LY (50.73\%), suggesting that temporary effects of HY are important in determining the variance of this trait. Similarly, the HY effect accounted for $50.37 \%$ of MY variance. With regard to other milk traits, the proportion of phenotypic variance explained by the HY effect varied from $6.16 \%$ (LP) to $12.52 \%$ (L:P). Finally, the HY effect was 6.11 , $3.56,2.63,10.55$, and $2.74 \%$ for MAS, KET, MFV, CYS, and RET, respectively, which suggested that the environmental HY effect had a moderate to low effect on the phenotypic variance of the health traits.

\section{Phenotypic and Genetic Correlations}

All $r_{p}$ between health and production traits were very weak, with the greatest association estimated between LY and CYS $\left(\mathrm{r}_{\mathrm{p}}=0.074\right.$; Table 5), highlighting that, at phenotypic level, no association exists between lactose and its ratios with health traits. Mastitis was unfavorably genetically correlated with LY (0.518 \pm 0.057$)$, favorably and weakly associated with LP $(-0.175 \pm$ 0.049), and almost uncorrelated with L:F, L:P, and L:S (Table 5). In addition, MAS was positively genetically correlated with SCS $\left(\mathrm{r}_{\mathrm{a}}=0.623 \pm 0.056\right.$ and $\mathrm{r}_{\mathrm{p}}=0.158$ $\pm 0.060)$ and LP was negatively related to SCS $\left(\mathrm{r}_{\mathrm{a}}=\right.$ $-0.245 \pm 0.018$ and $\left.r_{p}=-0.288 \pm 0.003\right)$ and MY $\left(r_{a}\right.$ $=-0.175 \pm 0.018)$ in the first 150 DIM. These findings were similar to results of Bastin et al. (2016), who reported $r_{a}$ between LP and MAS of -0.10 and -0.24 for the observation periods 5 to 305 and 5 to 65 DIM, respectively. Lactose yield was positively genetically correlated with KET $(0.420 \pm 0.077)$, MFV $(0.219 \pm$

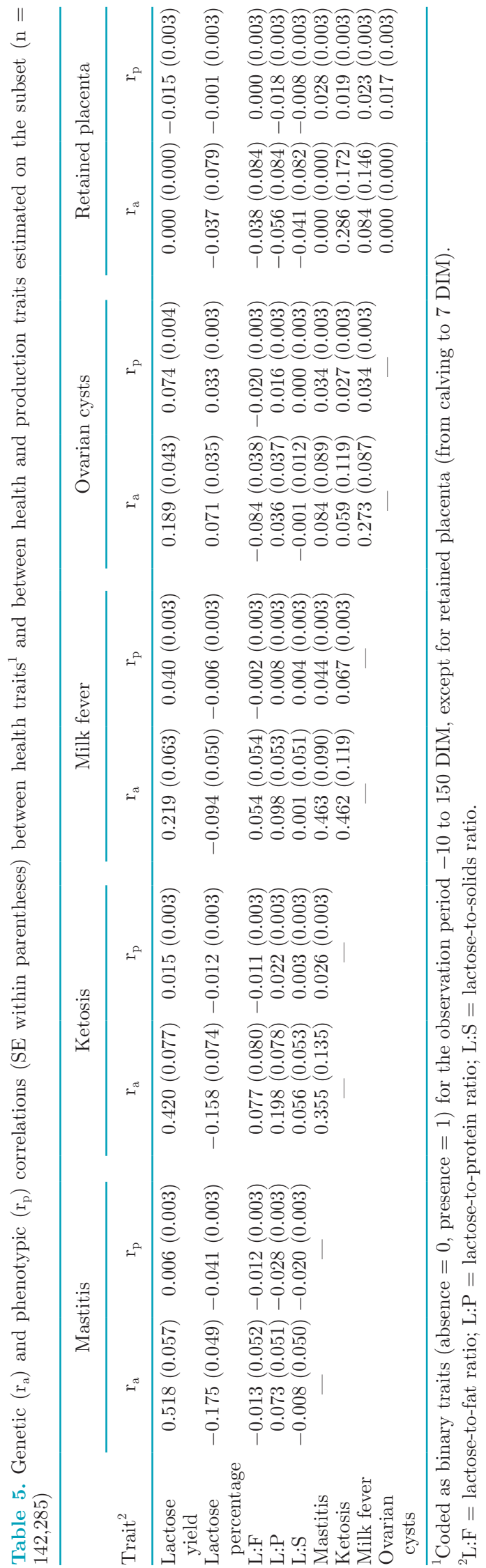

Journal of Dairy Science Vol. 102 No. 5, 2019 
$0.063)$, and CYS $(0.189 \pm 0.043)$. In addition, KET was genetically associated with L:P $(0.198 \pm 0.078)$ and LP $(-0.158 \pm 0.074)$. All other $\mathrm{r}_{\mathrm{a}}$ of LY, LP, and ratios with health traits were $<0.10$ (Table 5 ).

Phenotypic correlations between health traits were almost zero, with the greatest estimate between KET and MFV (0.067). At the genetic level, MAS positively related to other diseases typical of early lactation [i.e., KET (0.355 \pm 0.135$)$ and MFV $(0.463 \pm 0.090)]$. Both correlations were in the ranges of previous studies (Pryce et al., 2016) and suggested that selection against MAS leads to favorable correlated responses in other diseases (Pfeiffer et al., 2015). Supporting this view, Pryce et al. (2016) suggested that a general cow's robustness is responsible for its susceptibility to get sick. The $\mathrm{r}_{\mathrm{a}}$ of CYS with MAS, KET, and MFV were positive, suggesting that partly there could be common genetic background between these traits; in particular, the greatest $r_{a}(0.273)$ was estimated between CYS and MFV. Considering that the $r_{p}$ between CYS and MFV was almost zero, these findings suggested that genetically MFV could predispose cows to CYS during the first 150 DIM and that daughters of bulls with high EBV for MFV are supposed to be at higher risk of developing CYS compared with offspring of bulls with lower EBV for MFV. This could be related to the altered mineral metabolism in presence of MFV that could impair the hormonal regulation. In addition, it is fair to state that cow susceptibility also depends on the interaction between genotype and environment; this could explain the higher $r_{a}$ between MAS and CYS (0.16) reported in an earlier study on the same breed (Pfeiffer et al., 2015). Finally, RET was genetically $(0.286 \pm 0.172)$ associated with KET (Table 5).

All correlations estimated in the present study were in the ranges reported by Ingvartsen et al. (2003), who reviewed genetic associations between milk performance and cow health, and by Van Dorp et al. (1998), who estimated the correlation between 305-d MY and health disorders in Holstein cows. These findings confirmed that the genetic background of high-producing cows makes them more susceptible to diseases than that of cows yielding less milk (Ingvartsen et al., 2003; Oltenacu and Broom, 2010) and confirmed that LP is favorably genetically related to cows' energy balance and udder health (Bastin et al., 2016).

\section{CONCLUSIONS}

Cows with lower milk LP had higher frequency of udder health and metabolic disorders. The amount of $\mathrm{LP}$ variance due to additive genetic effects was $>50 \%$ and the genetic correlation with MAS in the first 150 DIM was negative. Genetic and phenotypic correlations of LY almost mirrored those of MY. Ratios including LP and other milk composition traits did not genetically correlate with health traits, except for the weak positive genetic relationship between L:P and KET. Based on the findings of the present study, LP is a valid candidate as an udder health indicator in early lactation. In fact, high heritability coupled with great data availability make LP a potential phenotype to be considered in the FV breeding program for mastitis resistance and udder health, thus far including lowly to moderately heritable traits such as MAS, SCC, and udder conformation traits.

\section{ACKNOWLEDGMENTS}

This study was supported by the University of Padova (Ricerca Scientifica fondi DOR - 2017, project DOR1721792/17, Italy). The first author thanks the Fondazione Ing. Aldo Gini (Padova, Italy) for funding the research period at University of Natural Resources and Life Sciences Vienna (BOKU, Vienna, Austria).

\section{REFERENCES}

Aschenbach, J. R., N. B. Kristensen, S. S. Donkin, H. M. Hammon, and G. B. Penner. 2010. Gluconeogenesis in dairy cows: The secret of making sweet milk from sour dough. IUBMB Life 62:869-877.

Bastin, C., L. Théron, A. Lainé, and N. Gengler. 2016. On the role of mid-infrared predicted phenotypes in fertility and health dairy breeding programs. J. Dairy Sci. 99:4080-4094.

Bauman, D. E., and W. B. Currie. 1980. Partitioning of nutrients during pregnancy and lactation: Review of mechanisms involving homeostasis and homeorhesis. J. Dairy Sci. 63:1514-1529.

Beerda, B., W. Ouweltjes, L. B. J. Šebek, J. J. Windig, and R. F. Veerkamp. 2007. Effects of genotype by environment interactions on milk yield, energy balance, and protein balance. J. Dairy Sci. 90:219-228.

Belay, T. K., M. Svendsen, Z. M. Kowalski, and T. Ådnøy. 2017. Genetic parameters of blood $\beta$-hydroxybutyrate predicted from milk infrared spectra and clinical ketosis, and their associations with milk production traits in Norwegian Red cows. J. Dairy Sci. 100:6298-6311.

Braunvieh Austria. 2018. Mastitis und hohe Zellzahlen-Ursachen und Vorbeugung. Accessed Nov. 21, 2018. http://www.braunviehaustria .at/home/ausgabe-news/article/mastitis-und-hohe-zellzahlen -ursachen-und-vorbeugung.html.

Buckley, F., K. O'Sullivan, J. F. Mee, R. D. Evans, and P. Dillon. 2003. Relationships among milk yield, body condition, cow weight, and reproduction in spring-calved Holstein-Friesians. J. Dairy Sci. 86:2308-2319.

Cant, J. P., D. R. Trout, F. Qiao, and N. G. Purdie. 2002. Milk synthetic response of the bovine mammary gland to an increase in the local concentration of arterial glucose. J. Dairy Sci. 85:494-503.

Cinar, M., U. Serbester, A. Ceyhan, and M. Gorgulu. 2015. Effect of somatic cell count on milk yield and composition of first and second lactation dairy cows. Ital. J. Anim. Sci. 14:105-108.

Costa, A., N. Lopez-Villalobos, G. Visentin, M. De Marchi, M. Cassandro, and M. Penasa. 2018. Heritability and repeatability of milk lactose and its relationships with traditional milk traits, somatic cell score and freezing point in Holstein cows. Animal. https://doi .org/10.1017/S1751731118002094.

Ebrahimie, E., F. Ebrahimi, M. Ebrahimi, S. Tomlinson, and K. R. Petrovski. 2018. A large-scale study of indicators of sub-clinical mastitis in dairy cattle by attribute weighting analysis of milk 
composition features: Highlighting the predictive power of lactose and electrical conductivity. J. Dairy Res. 85:193-200.

Ederer, S., C. Egger-Danner, W. Zollitsch, and B. Fuerst-Waltl. 2014. Metabolic disorders and their relationships to milk production traits in Austrian Fleckvieh. In Proc. of the 39th International Committee for Animal Recording (ICAR) meeting, Berlin, Germany. Accessed Jul. 10, 2018. https://www.icar.org/wp-content/ uploads/2015/09/Fuerst_Waltl.pdf.

Egger-Danner, C., J. B. Cole, J. E. Pryce, N. Gengler, B. Heringstad, A. Bradley, and K. F. Stock. 2015. Invited review: Overview of new traits and phenotyping strategies in dairy cattle with a focus on functional traits. Animal 9:191-207.

Egger-Danner, C., B. Fuerst-Waltl, W. Obritzhauser, C. Fuerst, H. Schwarzenbacher, B. Grassauer, M. Mayerhofer, and A. Koeck. 2012. Recording of direct health traits in Austria-Experience report with emphasis on aspects of availability for breeding purposes. J. Dairy Sci. 95:2765-2777.

Egger-Danner, C., W. Obritzhauser, B. Fuerst-Waltl, B. Grassauer, R. Janacek, F. Schallerl, C. Litzllachner, A. Koeck, M. Mayerhofer, M. Miesenberger, G. Schoder, F. Sturmlechner, A. Wagner, and K. Zottl. 2010. Registration of health traits in Austria - Experience review. In Proc. of the 37th International Committee for Animal Recording (ICAR) meeting, Riga, Latvia. Accessed Jul. 24, 2018. https://www.icar.org/Documents/Riga_2010/ppt/Egger-Danner .pdf

Fox, P. F., T. Uniacke-Lowe, P. L. H. McSweeney, and J. A. O'Mahoni. 2015. Dairy Chemistry and Biochemistry. Springer International Publishing, Basel, Switzerland.

Francisco, C. C., L. J. Spicer, and M. E. Payton. 2003. Predicting cholesterol, progesterone, and days to ovulation using postpartum metabolic and endocrine measures. J. Dairy Sci. 86:2852-2863.

Fuerst, C., A. Koeck, C. Egger-Danner, and B. Fuerst-Waltl. 2011. Routine genetic evaluation for direct health traits in Austria and Germany. Interbull Bull. 44:210-215.

Fuerst-Waltl, B., C. Fuerst, W. Obritzhauser, and C. Egger-Danner. 2016. Sustainable breeding objectives and possible selection response: Finding the balance between economics and breeders' preferences. J. Dairy Sci. 99:9796-9809.

Gillon, A., C. Bastin, H. Soyeurt, and N. Gengler. 2010. Genetic parameters of mastitis-correlated milk components in first parity dairy cows. Page 27 in Proc. 9th World Congress on Genetics Applied to Livestock Production, 1-6 August, Leipzig, Germany. German Society for Animal Science, Gießen, Germany. Accessed Sep. 15, 2018. http://hdl.handle.net/2268/69462.

Gilmour, A. R., B. J. Gogel, B. R. Cullis, S. J. Welham, and R. Thompson. 2015. ASReml User Guide. VSN Int. Ltd., Hemel Hempstead, UK.

Gohary, K., M. W. Overton, M. Von Massow, S. J. LeBlanc, K. D. Lissemore, and T. F. Duffield. 2016. The cost of a case of subclinical ketosis in Canadian dairy herds. Can. Vet. J. 57:728-732.

Gonçalves, J. L., R. I. Cue, B. G. Botaro, J. A. Horst, A. A. Valloto, and M. V. Santos. 2018. Milk losses associated with somatic cell counts by parity and stage of lactation. J. Dairy Sci. 101:43574366.

Gottardo, P., M. Penasa, F. Righi, N. Lopez-Villalobos, M. Cassandro, and M. De Marchi. 2017. Fatty acid composition of milk from Holstein-Friesian, Brown Swiss, Simmental and Alpine Grey cows predicted by mid-infrared spectroscopy. Ital. J. Anim. Sci. 16:380389 .

Hadrich, J. C., C. A. Wolf, J. Lombard, and T. M. Dolak. 2018. Estimating milk yield and value losses from increased somatic cell count on US dairy farms. J. Dairy Sci. 101:3588-3596.

Haile-Mariam, M., and J. E. Pryce. 2017. Genetic parameters for lactose and its correlation with other milk production traits and fitness traits in pasture-based production systems. J. Dairy Sci. 100:3754-3766.

Heringstad, B., Y. M. Chang, D. Gianola, and G. Klemetsdal. 2005. Genetic analysis of clinical mastitis, milk fever, ketosis, and retained placenta in three lactations of Norwegian Red cows. J. Dairy Sci. 88:3273-3281.
Heringstad, B., G. Klemetsdal, and J. Ruane. 2000. Selection for mastitis resistance in dairy cattle: A review with focus on the situation in the Nordic countries. Livest. Prod. Sci. 64:95-106.

Hooijer, G. A., R. B. F. Lubbers, B. J. Ducro, J. A. M. van Arendonk, L. M. T. E. Kaal-Lansbergen, and T. van der Lende. 2001. Genetic parameters for cystic ovarian disease in Dutch Black and White dairy cattle. J. Dairy Sci. 84:286-291.

Ingvartsen, K. L., R. J. Dewhurst, and N. C. Friggens. 2003. On the relationship between lactational performance and health: Is it yield or metabolic imbalance that cause production diseases in dairy cattle? A position paper. Livest. Prod. Sci. 83:277-308.

International Committee for Animal recording (ICAR). 2017. Procedure 2 of Section 2 of ICAR Guidelines Computing of Accumulated Lactation Yield. Accessed Jul. 20, 2018. https://www.icar .org/Guidelines/02-Procedure-2-Computing-Lactation-Yield.pdf.

International Committee for Animal recording (ICAR). 2018. Best practice guide on udder health in European dairy farms using automatic milking systems \& other dairy technologies. Accessed Nov. 30, 2018. https://www.icar.org/wp-content/uploads/2018/ 08/BPG-Udder-Health.pdf.

Kedzierska-Matysek, M., Z. Litwińczuk, M. Florek, and J. Barłowska. 2011. The effects of breed and other factors on the composition and freezing point of cow's milk in Poland. Int. J. Dairy Technol. 64:336-342.

Koeck, A., C. Egger-Danner, C. Fuerst, W. Obritzhauser, and B. Fuerst-Waltl. 2010c. Genetic analysis of reproductive disorders and their relationship to fertility and milk yield in Austrian Fleckvieh dual-purpose cows. J. Dairy Sci. 93:2185-2194.

Koeck, A., B. Heringstad, C. Egger-Danner, C. Fuerst, and B. FuerstWaltl. 2010a. Comparison of different models for genetic analysis of clinical mastitis in Austrian Fleckvieh dual-purpose cows. J. Dairy Sci. 93:4351-4358.

Koeck, A., B. Heringstad, C. Egger-Danner, C. Fuerst, P. Winter, and B. Fuerst-Waltl. 2010b. Genetic analysis of clinical mastitis and somatic cell count traits in Austrian Fleckvieh cows. J. Dairy Sci. 93:5987-5995.

Koeck, A., F. Miglior, J. Jamrozik, D. F. Kelton, and F. S. Schenkel. 2013. Genetic associations of ketosis and displaced abomasum with milk production traits in early first lactation of Canadian Holsteins. J. Dairy Sci. 96:4688-4696.

Koeck, A., F. Miglior, D. F. Kelton, and F. S. Schenkel. 2012. Alternative somatic cell count traits to improve mastitis resistance in Canadian Holsteins. J. Dairy Sci. 95:432-439.

Larsen, T., and K. M. Moyes. 2015. Are free glucose and glucose6-phosphate in milk indicators of specific physiological states in the cow? Animal 9:86-93.

Leitner, G., U. Merin, and N. Silanikove. 2011. Effects of glandular bacterial infection and stage of lactation on milk clotting parameters: Comparison among cows, goats and sheep. Int. Dairy J. $21: 279-285$.

Løvendahl, P., and M. Riis Weisbjerg. 2017. Lactose in milk-How can lactose concentration data be beneficial in management and breeding? In Proc. of the 41st International Committee for Animal Recording (ICAR) meeting, Edinburgh, UK. Accessed Aug. 3, 2018. https://www.icar.org/wp-content/uploads/2017/06/37. -Edinburgh-2017-Peter-Lovendahl-Presentation.pdf.

Marchitelli, C., F. Signorelli, F. Napolitano, C. Grelet, N. Gengler, F. Dehareng, H. Soyeurt, K. L. Ingvartsen, M. T. Sørensen, T. Larsen, M. Crowe, and GplusE Consortium. 2018. Milk biomarkers to evaluate health status of mammary gland in high producing dairy cattle. Page 14 in Proc. 5th Dairycare Conference, 19-20 March, Thessaloniki, Greece. DairyCare Cost action FA1308. Accessed Sep. 10, 2018. https://www.dairycareaction.org/uploads/2/ 4/2/6/24266896/proceedings_online_version.pdf.

Miglior, F., A. Sewalem, J. Jamrozik, J. Bohmanova, D. M. Lefebvre, and R. K. Moore. 2007. Genetic analysis of milk urea nitrogen and lactose and their relationships with other production traits in Canadian Holstein cattle. J. Dairy Sci. 90:2468-2479.

Miglior, F., A. Sewalem, J. Jamrozik, D. M. Lefebvre, and R. K. Moore. 2006. Analysis of milk urea nitrogen and lactose and their effect on longevity in Canadian dairy cattle. J. Dairy Sci. 89:4886-4894. 
Mostert, P. F., E. A. M. Bokkers, C. E. van Middelaar, H. Hogeveen, and I. J. M. de Boer. 2018. Estimating the economic impact of subclinical ketosis in dairy cattle using a dynamic stochastic simulation model. Animal 12:145-154.

Neuenschwander, T. F. O., F. Miglior, J. Jamrozik, O. Berke, D. F. Kelton, and L. R. Schaeffer. 2012. Genetic parameters for producer-recorded health data in Canadian Holstein cattle. Animal 6:571-578.

Oltenacu, P. A., and D. M. Broom. 2010. The impact of genetic selection for increased milk yield on the welfare of dairy cows. Anim. Welf. 19:39-49.

Ouweltjes, W., B. Beerda, J. J. Windig, M. P. L. Calus, and R. F. Veerkamp. 2007. Effects of management and genetics on udder health and milk composition in dairy cows. J. Dairy Sci. 90:229 238.

Pfeiffer, C., C. Fuerst, V. Ducrocq, and B. Fuerst-Waltl. 2015. Short communication: Genetic relationships between functional longevity and direct health traits in Austrian Fleckvieh cattle. J. Dairy Sci. 98:7380-7383.

Pryce, J. E., K. L. Parker Gaddis, A. Koeck, C. Bastin, M. Abdelsayed, N. Gengler, F. Miglior, B. Heringstad, C. Egger-Danner, K. F. Stock, A. J. Bradley, and J. B. Cole. 2016. Invited review: Opportunities for genetic improvement of metabolic diseases. J. Dairy Sci. 99:6855-6873.

Rainard, P., G. Foucras, D. Boichard, and R. Rupp. 2018. Invited review: Low milk somatic cell count and susceptibility to mastitis. J. Dairy Sci. 101:6703-6714.

Reist, M., D. Erdin, D. von Euw, K. Tschuemperlin, H. Leuenberger, Y. Chilliard, H. M. Hammon, C. Morel, C. Philipona, Y. Zbinden, N. Kuenzi, and J. W. Blum. 2002. Estimation of energy balance at the individual and herd level using blood and milk traits in highyielding dairy cows. J. Dairy Sci. 85:3314-3327.

Rollin, E., K. C. Dhuyvetter, and M. W. Overton. 2015. The cost of clinical mastitis in the first 30 days of lactation: An economic modeling tool. Prev. Vet. Med. 122:257-264.

Sargolzaei, M., H. Iwaisaki, and J. J. Colleau. 2006. CFC: A tool for monitoring genetic diversity. In Proc. 8th World Congress on Ge- netics Applied to Livestock Production, 13-18 August, Belo Horizonte, Brazil. Accessed Aug. 20, 2018. http://www.wcgalp.org/ proceedings/2006/cfc-tool-monitoring-genetic-diversity.

Sneddon, N. W., N. Lopez-Villalobos, S. R. Davis, R. E. Hickson, and L. Shalloo. 2015. Genetic parameters for milk components including lactose from test day records in the New Zealand dairy herd. N. Z. J. Agric. Res. 58:97-107.

Stoop, W. M., H. Bovenhuis, and J. A. M. van Arendonk. 2007. Genetic parameters for milk urea nitrogen in relation to milk production traits. J. Dairy Sci. 90:1981-1986.

Tiezzi, F., D. Pretto, M. De Marchi, M. Penasa, and M. Cassandro. 2013. Heritability and repeatability of milk coagulation properties predicted by mid-infrared spectroscopy during routine data recording, and their relationships with milk yield and quality traits. Animal 7:1592-1599.

Van Dorp, T. E., J. C. M. Dekkers, S. W. Martin, and J. P. T. M. Noordhuizen. 1998. Genetic parameters of health disorders, and relationships with 305-day milk yield and conformation traits of registered Holstein cows. J. Dairy Sci. 81:2264-2270.

Visentin, G. S. McParland, M. De Marchi, A. McDermott, M. A Fenelon, M. Penasa, and D. P. Berry. 2017. Processing characteristics of dairy cow milk are moderately heritable. J. Dairy Sci. 100:6343-6355.

Zentrale Arbeitsgemeinschaft österreichischer Rinderzüchter (ZAR) 2018. Jahresbericht 2017. Accessed August 4, 2018. http://www .zar.at/Downloads/Jahresberichte/ZAR-Jahresberichte.html.

Zhao, F. Q. 2014. Biology of glucose transport in the mammary gland. J. Mammary Gland Biol. Neoplasia 19:3-17.

ZuchtData. 2017. Jahresbericht 2017. ZuchtData EDV-Dienstleistungen GmbH. Accessed Aug. 4, 2018. https://www.zar.at/dam/jcr: 3717cba9-71ae-4b7e-93f1-dae9d51c2fdf/ZuchtData-Jahresbericht \%202017.pdf

Zwald, N. R., K. A. Weigel, Y. M. Chang, R. D. Welper, and J. S. Clay. 2004. Genetic selection for health traits using producer recorded data. I. Incidence rates, heritability estimates, and sire breeding values. J. Dairy Sci. 87:4287-4294. 